Safety and efficacy of continuous or intermittent enteral nutrition in ICU patients: Systematic review of clinical evidence

Francesco De Lazzaro ${ }^{1}$ M.D., Francesco Alessandri ${ }^{1}$ M.D., Maria Grazia Tarsitano ${ }^{2}$ M.D., Federico Bilotta ${ }^{1}$ M.D. and Francesco Pugliese ${ }^{1}$ M.D.

${ }^{1}$ Department of Anesthesiology, Critical Care and Pain Medicine, "Sapienza"

University of Rome, Policlicnico Umberto I, Rome, Italy

${ }^{2}$ Department of Experimental Medicine, Sapienza University of Rome, Italy

\title{
Words: 3189
}

Corresponding Author: Francesco De Lazzaro M.D.

Department of Anesthesiology, Critical Care and Pain Medicine,

"Sapienza" University of Rome, Policlinico Umberto I, Rome, Italy

Viale del Policlinico 155,

Rome, Italy 00161

Tel. +39-0649978024

E-mail: franzdelazzaro@gmail.com;

\section{Conflict of Interest Statement}

None declared.

\section{Financial disclosure}

None declared

This article has been accepted for publication and undergone full peer review but has not been through the copyediting, typesetting, pagination and proofreading process, which may lead to differences between this version and the Version of Record. Please cite this article as doi: 10.1111/jpen.2316.

This article is protected by copyright. All rights reserved. 
Review Registration: PROSPERO CRD42020148483

\section{Abstract}

The best mode of delivering enteral nutrition (EN) in ICU is still debated: several consensus guidelines (ASPEN and ESPEN) suggest that EN in ICU should be preferably delivered continuously rather intermittently but some authors highlight that the first is unphysiological. The aim of this systematic review (SR) is to summarize available clinical evidence related to safety and efficacy of continuous enteral nutrition (C-EN) or intermittent enteral nutrition (I-EN) in ICU patients, in relation to appropriated supply on nutritional status, gastrointestinal symptoms or tolerance, risks on respiratory tract infections. A literature search of Pubmed, EMBASE and Google Scholar was performed comparing C-EN vs I-EN and 4196 published studies were screened. Nineteen studies were selected for this SR reporting types of ICU, nutritional protocols and study period. Effects of C-EN vs I-EN were presented according to the impact on: nutritional status, digestive tract and respiratory tract. The contrasting results confirmed that the optimal delivering mode of EN remains controversial. Future studies dedicated to identify the benefits and limitations of CEN or I-EN should be realized. 


\section{Introduction}

Enteral nutrition (EN) is a relevant therapeutic support for ICU patients. A delayed commencement is associated with a higher rate of infective complications and an increased mortality in some particular subsets of patients (i.e. traumatic brain injury) [1-3]. Appropriate nutrition should address 2 major endpoints: adequate energy supply and optimal composition of macronutrients [4-6]. EN can be delivered in a continuous (C-EN) or intermittent (I-EN) mode, and I-EN can be administered in cyclic, intermittent or bolus infusions [7]. Several consensus guidelines as those delivered by the Society of Critical Care Medicine (SCCM), the American Society for Parenteral and Enteral Nutrition (ASPEN) and the European Society for Parental and Enteral Nutrition (ESPEN) suggest that -when possible- EN should be initiated within the first 48 hours after ICU admission [1,5]. According to the ESPEN guidelines EN in ICU should be preferably delivered as C-EN rather than I-EN because of the lower incidence of associated diarrhea [5]. The same guidelines underline the lack of proven benefits in other outcome measures and highlight the uncertainty on the impact of either C-EN or I-EN on major outcomes as morbidity and mortality [5]. Despite this background, several authors have challenged the superiority of C-EN when compared with I-EN and highlighted that C-EN is unphysiological and I-EN is 
associated with more pronounced stimulatory effect on protein synthesis in healthy volunteers and in animal models [8-12]. The optimal mode of EN delivery in ICU patients remains controversial being listed among the top 10 "open questions" [1214].

The aim of this systematic review (SR) is to summarize available clinical evidence on the safety and efficacy of C-EN vs I-EN in ICU patients.

\section{Methods}

This SR was performed in accordance with the PRISMA (Preferred Reporting and Items for Systematic Reviews and Meta Analyses) recommendations and was recorded in the Prospero register (registration number: CRD42020148483). Two authors (FDL and FA) independently screened and assessed titles, abstracts and full text of retrieved articles of papers published between January 1980 to April 2020 [15-17]. To identify articles suitable for this SR, a literature search of PubMed, EMBASE and Google Scholar was completed and the reference section of related studies was searched. Studies conducted as prospective randomized controlled trials $(\mathrm{RCT})$, prospective and retrospective observational studies, case series, and case reports, published as full paper in English were considered eligible. The following key words were searched: "enteral nutrition" "enteral feeding", "nasogastric feeding" combined with "or", "vs", or "and" with "continuous", "intermittent" and "bolus". We selected studies on ICU patients receiving C-EN or I-EN, delivered through naso, oro-gastric, jejunal, or percutaneous enteral gastrostomy (PEG) tube feeding. We excluded studies involving pediatric and non-ICU patients as well as studies whose population received combined EN and PN supply. Disagreement over eligibility was resolved through open discussion. After screening and revision of 
the full text, duplicates were eliminated. Details of the studies were recorded using a dedicated data-extraction form. GRADE Cochrane approach was used for quality of

evidence of the studies and to eliminate risk of bias. Outcomes were categorized in 3 major outcomes: C-EN vs I-EN on nutritional status, gastrointestinal symptoms or tolerance and respiratory tract.

\section{Results}

Of the 4196 published studies screened 19 were selected as appropriate for this SR: 15 RCTs, 3 prospective and 1 retrospective observational studies (Figure 1) [18-36]. Out of the 18 selected studies, 12 were conducted in general mixed ICU, 4 in neurosurgical or neurological ICU, 2 in trauma ICU (1 medical ICU and 1 surgical ICU), and 1 in general mixed and in cardiac surgery ICU. Nutritional protocols tested in these studies were evaluated for safety and efficacy of C-EN vs. I-EN; study period ranged from 24 hours to 17 days (in 1 study the duration of the study was not specified); the follow up ranged between 24 hours to 66 days. Target energy supply differed between studies: $25 \mathrm{kcal} / \mathrm{kg} /$ day in 5, 25/30 kcal/kg/day in 2, $30 \mathrm{kcal} / \mathrm{kg} /$ day in 2, calculated using Harris-Benedict formula in 2, according Wilmore measurement in 1 , estimated requirement by physician in 1 and it was not specified in 6 (Table 1).

Nutrition protocols, according the description reported by the authors, included various modes: in 15 studies C-EN was infused for 24 hours at 10 to 120 $\mathrm{ml} / \mathrm{h}$ rate and compared with I-EN infused as "bolus with electronic infusion pump" in 4 studies (with 6-8 injection/day of 40 to $480 \mathrm{ml}$ in 30-60 min); as "bolus with manual syringe" in 4 studies (6 injection/day of 40 to $320 \mathrm{ml}$ from $5 \mathrm{~min}$ to 1 hour); as "bolus forced by gravity" in 2 studies (4-6 injections/day of 125 to $350 \mathrm{ml}$ in 15-20 min); as "cyclic" in 5 studies at 28 to $112 \mathrm{ml} / \mathrm{h}$ rate, with continuous infusion for 16 hours 
followed by 8 hours interruption during the night in 2 studies and continuous for 18 hours followed by 6 hours interruption in 3 studies (Supplementary 1 ). In two studies

C-EN was not infused continually: in 1 it was infused for 18 hours with 6 hours interruption during the night and compared with I-EN administered as 6 boluses/day (every 3 hours for 18 hours and 6 hours interruption during the night); in 1 study CEN was infused for 4 hours followed by 1 hour of interruption and compared with IEN administered with 6-8 boluses/day followed by 6 hours of suspension during the night. In 2 studies the C-EN and I-EN protocols were not specified. Nutrition, either C-EN or I-EN, was delivered by enteral route using various approaches: through nasogastric tube in 11 studies, orogastric tube in 1, nasogastric or orogastric tube in 2, nasogastric or nasojejunal in 1, PEG in 1 and was not specified in 3 (Table 2). Effects of C-EN vs I-EN will be presented according to the impact on: nutritional status, gastrointestinal symptoms or tolerance and respiratory tract (Table 3-5). The risk of bias in RCT and in non-RCT is also reported (Tables 5 and 6). Within each presented end point, data supported by the larger number of patients will be displayed first.

\section{C-EN vs I-EN and effects on nutritional status}

Nutritional status, achieved with C-EN or I-EN, was recorded in 14 of the selected studies (11 RCT, 2 prospective and 1 retrospective observational studies) that enrolled a total of 921 patients [16, 22-27, 29, 30, 32-36]. Measured variables to describe the impact of C-EN or I-EN on the nutritional status, included: number of days in whom "caloric prescribed goal" was achieved, daily amount of delivered feeding volume, time to achieve "caloric prescribed goal", number of patients 
achieving target of caloric and protein goal, serum concentration of prealbumin or blood glucose, mean weight loss, mean daily calorie intake, glycemic variability and insulin utilization, incretion of grelin and leptin, respiratory quotient $(R Q)$ and resting energy expenditure (REE), change in rectus femoris cross-sectional area and plasma concentrations of amino acids (Table 2).

The number of days in which the caloric target was reached, was recorded in 4 RCTs that enrolled a total of 247 patients and reported conflicting results: in $1 \mathrm{RCT}$ patients assigned to C-EN achieved "caloric prescribed goal" less days than those that received I-EN; 1 RCT reported that patients assigned to $\mathrm{C}-\mathrm{EN}$ achieved "caloric prescribed goal" more days than those that received I-EN and 2 RCTs showed no difference between C-EN or I-EN [22, 25, 27, 32]. Daily amount of delivered feeding volume was recorded in 4 RCTs that enrolled a total of 225 patients and reported conflicting results: in $1 \mathrm{RCT}$ patients assigned to $\mathrm{C}-\mathrm{EN}$ received smaller feeding volume than those that received I-EN; in 2 RCTs patients assigned to C-EN received larger feeding volume than those receiving I-EN on day $1^{\text {st }}$ but feeding volumes were equivalent on day $3^{\text {rd }}$ and 1 RCT showed no difference between the 2 groups $[25,26$, 30, 34]. Time (in days) necessary to achieve "prescribed caloric goal" was recorded by 4 studies that enrolled a total of 396 patients and reported conflicting results: 1 RCT reported that patients assigned to C-EN achieved "prescribed caloric goal" later than those treated with I-EN; 1 retrospective observational study reported that patients assigned to C-EN achieved prescribed caloric goal earlier than those treated with I-EN and 2 studies showed no differences between C-EN and I-EN treated patients $[19,23,27,34]$. Number of patients achieving $80 \%$ of caloric and protein goal was recorded in $1 \mathrm{RCT}$ that enrolled a total of 121 patients: there were more patients assigned to I-EN group who achieved $80 \%$ of caloric and protein goal than 
those treated with C-EN [36]. Prealbumin serum concentration was recorded in 3 studies that enrolled a total of 104 patients and reported conflicting results: 2 RCTs showed no difference between C-EN or I-EN and 1 prospective observational study reported an increase in prealbumin serum concentration in patients treated with CEN after 3 days while in those that received I-EN it remained constant [22, 33, 35]. Effects of C-EN or I-EN on blood glucose concentration was recorded in 2 studies that enrolled a total of 89 patients: these studies showed that both C-EN and I-EN ensure blood glucose concentration values consistently within the normal range [29, 33]. Daily mean caloric intake was evaluated in $1 \mathrm{RCT}$ that enrolled a total of 43 patients divided in 3 sub-groups: I-EN, C-EN or jejunal C-EN. Patients assigned to jejunal C-EN received higher daily caloric intake, due to lower rate of interruptions in delivery, than those in the other 2 study groups [24].

\section{C-EN vs I-EN on gastrointestinal symptoms or tolerance}

Evidence that are related to the impact of C-EN or I-EN on gastrointestinal symptoms or tolerance were reported in 18 of the selected studies (14 RCTs, 3 prospective and 1 retrospective observational studies) that enrolled a total of 1024 patients [18-32, 34-36]. These include: diarrhea, gastric residual volume (GRV), vomiting, changes in gastric $\mathrm{pH}$ and in digestive tract colonization, abdominal distension and constipation (Table 3).

The incidence or severity of diarrhea was recorded among the registered outcome measures in 12 studies (10 RCT, 1 retrospective and 1 prospective observational studies) that enrolled a total of 714 patients and reported no differences in the incidence or severity of diarrhea in patients that received C-EN or 
I-EN $[18,19,22,23,25,27,29-32,35,36]$. The GRV was evaluated in 12 studies that enrolled a total of 809 patients [19, 22, 23-27, 29, 31, 32, 35, 36]. Nine RCTs showed no difference between the 2 study groups; in 2 studies patients assigned to C-EN achieved earlier the nutrition target as had lower GRV and less interruptions in the administration. One study also demonstrated that patients receiving C-EN required less use of prokinetics (metoclopramide) [29]. Vomiting was evaluated in 5 studies (4 RCTs and 1 prospective observational study) that enrolled a total of 267 patients and reported no difference between C-EN and I-EN treated patients $[25,30$, $32,35,36]$. Changes in gastric $\mathrm{pH}$ and in digestive tract colonization were evaluated in 4 studies (3 RCTs and 1 prospective observational study) that enrolled a total of 156 patients $[20,21,24,28]$. Three studies showed stable $\mathrm{pH}$ values in patients receiving $\mathrm{C}-\mathrm{EN}$ and a decrease in $\mathrm{pH}$ values during the interruption of nutrition supply in those receiving I-EN; 1 study reported no difference between C-EN and IEN treated patients. Digestive tract colonization resulted to be similar between C-EN and I-EN treated patients according 2 studies; 1 RCT report that, at day $6^{\text {th }}$, the variety and number of digestive colonization microorganism is higher in patients receiving C-EN than in I-EN; 1 RCT proved that both C-EN and I-EN, when administered at gastric level, are associated with the potential for higher pathogenic digestive colonization than jejunal C-EN. Abdominal distention was evaluated in 2 studies that enrolled a total of 68 patients with no difference between C-EN and I-EN treated patients $[25,30]$. Constipation was evaluated in 1 RCT that enrolled a total of 30 patients and reported higher incidence of constipation in patients receiving C-EN than in I-EN [31]. 


\section{C-EN vs I-EN on respiratory tract}

Effects of C-EN and I-EN on the respiratory tract was reported in 12 of the selected studies (10 RCTs 1 prospective and 1 retrospective observational studies) that enrolled a total of 708 patients [18-20, 22, 23, 25-31]. These included: presence of EN in tracheobronchial (TBA) secretions, incidence of pneumonia, changes in respiratory tract colonization, length of ICU stay and extubation rate (Table 4).

Presence of EN in TBA secretions was evaluated in 8 studies (7 RCTs and 1 prospective observational study) that enrolled a total of 296 patients $[18,19,22,25$, 26, 29-31]. Seven studies reported no difference in the rate of EN in TBA secretions between C-EN and I-EN treated patients; 1 RCT reported higher rate of EN in TBA in C-EN than in I-EN patients. Incidence of pneumonia was evaluated in 6 studies (4 RCTs, 1 prospective and 1 retrospective observational studies) that enrolled a total of 480 patients and proved no difference between C-EN or I-EN patients [20, 23, 25, $27,28,30]$. Changes in respiratory tract colonization was evaluated in 2 RCTs that enrolled a total of 100 patients and reported no difference between C-EN than in IEN patients $[20,28]$. Length of ICU stay were reported in 2 RCTs that enrolled a total of 228 patients with no differences [26, 36]. Extubation rate after 21 days was recorded in $1 \mathrm{RCT}$ that enrolled a total of 107 patients: a lower rate of successful extubation were recorded in C-EN than in I-EN patients [26].

\section{Discussion}

This SR summarizes clinical evidence related to safety and efficacy of C-EN or I-EN in ICU patients. Recorded variables address 3 major subsets: effects on nutritional status, gastrointestinal symptoms and tolerance and respiratory tracts. 
Evidence on nutritional status are controversial regarding the efficacy in nutrition supplying (i.e. days in whom "caloric prescribed goal" was achieved, amount of delivered feeding volume, time to achieve "caloric prescribed goal")

Evidence on the effects on gastrointestinal symptoms or tolerance suggest that there are no differences in EN complications (diarrhea, vomiting, abdominal distension) but C-EN associates with lower GRV while I-EN associates with better evidence on digestive tract colonization and constipation.

Evidence on the effects on respiratory tract suggest that there are no differences in EN-related complications (pneumonia, changes in respiratory tract colonization and ICU length of stay). Despite most of the studies showed similar results in the rate of EN in TBA, in 1 study I-EN appears to be superior to C-EN for shorter duration of mechanical ventilation.

Of interest ASPEN and ESPEN suggestions, that address C-EN as possibly preferable, seems not supported by strong available evidence as also mentioned in the original document. The ASPEN report it as "expert consensus" and ESPEN refer to it as "grade B, strong consensus". [37] In 2014 a SR, intended to report data on the effectiveness of C-EN or I-EN from studies published before January 2011 , analyzed data from 5 RCTs and concluded that available evidences were insufficient to favor either C-EN or I-EN mode [38]. Compared to that SR, the present manuscript is more comprehensive and included data from 19 original studies. Still the available evidence is insufficient to define ultimate indications on which nutrition mode is associated with better safety and efficacy profile. The ESPEN guidelines were published in 2019 and were based on dedicated meta-analysis of 4 RCTs that enrolled a total of 236. According to the presented results, C-EN is associated with 
lower incidence of diarrhea than I-EN [5]. In this SR we retrieved and presented a total of 12 studies presenting data on the incidence of diarrhea during C-EN or I-EN and the ultimate conclusions led to controversial evidence. Furthermore, several other conflicting results and methodological inconsistencies have now been highlighted.

Among the distinctive results of this $\mathrm{SR}$ is the huge difference in methodological approach used throughout the selected studies. More in particular, the study period ranged between 1 and 24 days; I-EN was administered in different modes in terms of times, flow rate and bolus feed administered; the exact amount of calories delivered was not uniform and calculated with different approach; the achievement of "prescribed caloric goal" was accepted as a different percentage to the total (from $75 \%$ to $100 \%$ ); the cutoff used to record GRV (from 75 to $300 \mathrm{ml}$ ) was various and distant from the actual guidelines to define these complication ( $>500$ $\mathrm{ml}$ (Table 1). Moreover, most studies did notreport separately symptoms of gastrointestinal intolerance (diarrhea, vomiting, constipations) [37]. Beside these inconsistencies, it is important to note that there is an open controversy on the optimal nutritional composition [39-43].

Among the possible study limitations of this SR is the selective inclusion only of studies that recruited patients treated in ICU. The exclusion of studies in hospitalized patients treated outside the ICU and of studies in non-hospitalized patients, might have excluded evidence that are of potential interest. Despite this limitation, we consider the ICU cohort a unique subset of enterally fed patients, given the severity of their clinical condition. As such, clinical recommendations need to be based on studies carried out within this environment. 
Another possible limitation is referable to the design of the selected studies. For this SR, we have considered suitable any study design and included RCTs but also prospective and retrospective observational studies. The Authors acknowledge the difference in the strength of evidence associated with various study design but, in order to present the most possible comprehensive data, have considered appropriate to report not only RCTs.

In conclusion, the evidence collected in this SR is not sufficient to provide clear indications on which nutritional mode, either C-EN or I-EN, should be preferred. Some results favor the use of C-EN (lower GRV and less need for prokinetic) while others support I-EN (better digestive tract colonization, lower constipation and less EN contamination of TBA secretions). Future studies should be dedicated to identify the benefits and limitations of C-EN or I-EN. The present SR can provide a background to design study protocols with an appropriate methodological approach and qualified endpoints. 


\section{References}

1.- McClave SA, Taylor BE, Martindale RG, et al for the Society of Critical Care Medicine and American Society for Parenteral and Enteral Nutrition. Guidelines for the provision and assessment of nutrition support therapy in the adult critically ill patient: Society of Critical Care Medicine (SCCM) and American Society for Parenteral and Enteral nutrition. (ASPEN). J Parenter Enteral Nutr. 2016; 40(2):159211.

2.- Marik PE, Zaloga GP. Early enteral nutrition in acutely ill patients: A systematic review. Crit Care Med. 2001;29(12):2264-2270

3.- Wang X, Dong Y, Han X, Qi XQ, Huang CG, Hou LJ. Nutritional support for patients sustaining traumatic brain injury: a systematic review and meta-analysis of prospective studies. PLoS One. 2013;8(3)

4.- Lewis SR, Schofield-Robinson OJ, Alderson P, Smith AF. Enteral versus parenteral nutrition and enteral versus a combination of enteral and parenteral nutrition for adults in the intensive care unit. Cochrane Database Syst Rev. 2018; 8;6 5.- Singer $P$, Blaser AR, Berger MM, et al. ESPEN guideline on clinical nutrition in the intensive care unit. Clin Nutr. 2019;38(1):48-79.

6.- Rothschild J, Lagakos W. Implications of enteral and parenteral feeding times: considering a circadian picture. JPEN J Parenter Enteral Nutr. 2015;39(3):266-70

7.- Ichimaru S. Methods of Enteral Nutrition Administration in Critically III Patients: Continuous, Cyclic, Intermittent, and Bolus Feeding. Nutr Clin Pract. 2018;33(6):790-795 
8.- Bear DE, Hart N and Puthucheary Z. Continuous or intermittent feeding: pros and cons. Curr Opin Crit Care. 2018;24(4):256-261.

9.- Chowdhury AH, Murray K, Hoad CL, et al. Effects of bolus and continuous nasogastric feeding on gastric emptying, small bowel water content, superior mesenteric artery blood flow, and plasma hormone concentrations in healthy adults: a randomized crossover study. Ann Surg. 2016;263:450

10.- Johnston JD, Ordovas JM, Scheer FA, et al. Circadian rhythms, metabolism, and chrononutrition in rodents and humans. Adv Nutr. 2016; 7:399-406.

11.- Gazzaneo MC, Suryawan A, Orellana RA, et al. Intermittent bolus feeding has a greater stimulatory effect on protein synthesis in skeletal muscle than continuous feeding in neonatal pigs. J Nutr 2011;141:2152

12.- Marik PE. Feeding critically ill patients the right 'whey': thinking outside of the box. A personal view. Ann Intensive Care. 2015;5(1):51.

13.- Arabi YM, Casaer MP, Chapman M, et al. The intensive care medicine research agenda in nutrition and metabolism. Intensive Care Med. 2017;43(9):1239-1256

14.-Patel JJ, Rosenthal MD, Heyland DK. Intermittent versus continuous feeding in critically ill adults. Curr Opin Clin Nutr Metab Care. 2018;21(2):116-120

15.-Willner D, Spennati V, Stohl S, Tosti G, Aloisio S, Bilotta F. Spine Surgery and Blood Loss: Systematic Review of Clinical Evidence. Anesth Analg. $2016 ; 123(5): 1307-1315$. 
16.-Hermanides J, Qeva E, Preckel B, Bilotta F. Perioperative hyperglycemia and neurocognitive outcome after surgery: a systematic review. Minerva Anestesiol. 2018;84(10):1178-1188.

17.-Bilotta F, Lauretta MP, Tewari A, Haque M, Hara N, Uchino H, Rosa G. Insulin and the Brain: A Sweet Relationship With Intensive Care. J Intensive Care Med. $2017 ; 32(1): 48-58$

18.-Trudy T, Taylor RN, M.S.N. A comparison between two methods of nasogastric tube feedings. J Neurosurg Nurs. 1982;14(1):49-55.

19.-Kocan MJ, Hickisch SM. A comparison of continuous and intermittent enteral nutrition in NICU patients. J Neurosci Nurs. 1986;18(6):333-7.

20.-Bonten MJ, Gaillard CA, Van der Hulst R, et al. Intermittent enteral feeding: the influence on respiratory and digestive tract colonization in mechanically ventilated intensive-care-unit patients. Am J Respir Crit Care Med. 1996;154(2 Pt 1):394-9.

21.-Spilker CA, Hinthorn DR, Pingleton SK. Intermittent enteral feeding in mechanically ventilated patients. The effect on gastric $\mathrm{pH}$ and gastric cultures. Chest. 1996;110(1):243-8.

22.-Steevens EC, Lipscomb AF, Poole GV, Sacks GS. Comparison of continuous vs intermittent nasogastric enteral feeding in trauma patients: perceptions and practice. Nutr Clin Pract. 2002;17(2):118-22.

23.-Rhoney DH, Parker D Jr, Formea CM, Yap C, Coplin WM. Tolerability of bolus versus continuous gastric feeding in brain-injured patients. Neurol Res. 2002;24(6):613-20. 
24.-Gowardman J, Sleigh J, Barnes N, Smith A, Havill J. Intermittent enteral nutrition--a comparative study examining the effect on gastric $\mathrm{pH}$ and microbial colonization rates. Anaesth Intensive Care. 2003;31(1):28-33.

25.-Serpa LF, Kimura M, Faintuch J, Ceconello I. Effects of continuous versus bolus infusion of enteral nutrition in critical patients. Rev Hosp Clin Fac Med Sao Paulo. 2003;58(1):9-14.

26.-Chen YC, Chou SS, Lin LH, Wu LF. The effect of intermittent nasogastric feeding on preventing aspiration pneumonia in ventilated critically ill patients. J Nurs Res. 2006; 14(3):167-80.

27.-MacLeod JB, Lefton J, Houghton D, Roland C, Doherty J, Cohn SM, Barquist ES. Prospective randomized control trial of intermittent versus continuous gastric feeds for critically ill trauma patients. J Trauma. 2007;63(1):57-61.

28.-Tamowicz B, Mikstacki A, Grzymisławski M. The Influence of the Feeding Therapy Model on Pulmonary Complications in Patients Treated under Conditions of Intensive Therapy. Advances in Clinical and Experimental Medicine 2007;16(3):365373

29.-Maurya I, Pawar M, Garg R, Kaur M, Sood R. Comparison of respiratory quotient and resting energy expenditure in two regimens of enteral feeding - continuous vs. intermittent in head-injured critically ill patients. Saudi J Anaesth. 2011;5(2):195-201 30.-Abdelsalam Y. Continuous versus bolus infusion of enteral nutrition in intensive care unit. AAMJ. 2012;10(3)

31.-Kadamani I, Itani M, Zahran E, Taha N. Incidence of aspiration and gastrointestinal complications in critically ill patients using continuous versus bolus This article is protected by copyright. All rights reserved. 
infusion of enteral nutrition: a pseudo-randomised controlled trial. Aust Crit Care. 2014;27(4):188-93.

32.-Tavares de Araujo VM, Gomes PC, Caporossi C. Enteral nutrition in critical patients; should the administration be continuous or intermittent? Nutr Hosp. 2014;29(3):563-7.

33.-Shahriari M, Rezaei E, Bakht LA, Abbasi S. Comparison of the effects of enteral feeding through the bolus and continuous methods on blood sugar and prealbumin levels in ICU inpatients. J Educ Health Promot. 2015;30(4):95.

34.-Evans DC, Forbes R, Jones C, et al. Continuous versus bolus tube feeds: Does the modality affect glycemic variability, tube feeding volume, caloric intake, or insulin utilization? Int J Crit IIIn Inj Sci. 2016;6(1):9-15.

35.-Yagan O, Tas N, Ayyildiz SN, Karakahya M, Noyan T. Comparison of the effects of continuous versus intermittent enteral feeding on plasma leptin and ghrelin levels in Intensive Care Units Rev Nutr. 2017;30(4).

36.- McNelly A S, Bear DE, Connolly B A et al. Effect of Intermittent or Continuous Feed on Muscle Wasting in Critical IIIness: A Phase 2 Clinical Trial Chest. 2020 Jul;158(1):183-194.

37.- Pletschette Z, Preiser JC Continuous versus intermittent feeding of the critically ill: have we made progress? Curr Opin Crit Care. 2020 Aug;26(4):341-345.

38.-Rosa Aguilera-Martinez RN, Emilia Ramis-Ortega RN, Concha CarrataláMunuera et al. Effectiveness of continuous enteral nutrition versus intermittent enteral nutrition in intensive care patients: a systematic review. JBI Database of Systematic Reviews \& Implementation Reports 2014;12(1): 281- 317. 
39.-Di Renzo L, Gualtieri P, Alwardat N et al. The role of IL-6 gene polymorphisms in the risk of lipedema.Eur Rev Med Pharmacol Sci. 2020;24(6):3236-3244.

40.-Merra G, Gualtieri P, Cioccoloni G, et al. FTO rs9939609 influence on adipose tissue localization in the Italian population. Eur Rev Med Pharmacol Sci.

$2020 ; 24(6): 3223-3235$

41.- Bilotta F, Rosa G. Optimal glycemic control in neurocritical care patients. Crit Care. 2012;16(5):163.

42.- Romano L, Bilotta F, Dauri M, Macheda S, Pujia A, De Santis GL, Tarsitano MG, Merra G, Di Renzo L, Esposito E, De Lorenzo A. Short Report - Medical nutrition therapy for critically ill patients with COVID-19. Eur Rev Med Pharmacol Sci. 2020;24(7):4035-4039.

43.- Van Dyck L, Casaer MP. Intermittent or continuous feeding: any difference during the first week? Curr Opin Crit Care. 2019;25(4):356-362

Table 1: Studies, number of patients, type of ICU and period of the selected studies

\begin{tabular}{|c|c|c|c|c|c|c|}
\hline Studies & $\begin{array}{l}\text { Type } \\
\text { of } \\
\text { study }\end{array}$ & $\begin{array}{l}\text { Patients } \\
\text { treated in } \\
\text { C-EN } \\
\text { group }\end{array}$ & $\begin{array}{l}\text { Patients } \\
\text { treated in } \\
\text { I-EN } \\
\text { group }\end{array}$ & $\begin{array}{l}\text { Type } \\
\text { of } \\
\text { ICU }\end{array}$ & $\begin{array}{l}\text { Study } \\
\text { Period } \\
\text { (days) }\end{array}$ & $\begin{array}{l}\text { Target } \\
\text { Energy } \\
\text { supply }\end{array}$ \\
\hline Trudy $1982^{18}$ & RCT & 8 & 5 & $\mathrm{NICU}$ & 24 & $\mathrm{~N} / \mathrm{A}$ \\
\hline Kocan $1986^{19}$ & RCT & 17 & 17 & $\mathrm{NICU}$ & 10 & Wilmore nomogram \\
\hline Bonten $1996^{20}$ & RCT & 60 & 60 & $\begin{array}{l}\text { ICU, } \\
\text { CS-ICU }\end{array}$ & 14 & $\mathrm{~N} / \mathrm{A}$ \\
\hline Spilker $1996^{21}$ & $\mathrm{PO}$ & 13 & 13 & ICU & 5 & $\mathrm{~N} / \mathrm{A}$ \\
\hline Steevens $2002^{22}$ & RCT & 9 & 9 & TICU & 7 & $25-30$ kcal/kg/day \\
\hline Rhoney $2002^{23}$ & $\mathrm{RO}$ & 66 & 86 & NICU & ns & Unit protocol \\
\hline Gowardman $2003^{24}$ & RCT & $\begin{array}{l}26 \\
(12+14) \text { * }\end{array}$ & 15 & $\mathrm{ICU}$ & 12 & $30 \mathrm{kcal} / \mathrm{kg} /$ day \\
\hline Serpa $2003^{25}$ & RCT & 14 & 14 & $\mathrm{ICU}$ & 3 & $25 \mathrm{kcal} / \mathrm{kg} /$ day \\
\hline Chen $2006^{26}$ & RCT & 51 & 56 & ICU & 7 & $25 \mathrm{kcal} / \mathrm{kg} /$ day \\
\hline Mac Leod $2007^{2 \prime}$ & RCT & 81 & 79 & TICU & 7 & $25 \mathrm{kcal} / \mathrm{kg} /$ day \\
\hline
\end{tabular}

This article is protected by copyright. All rights reserved. 


\begin{tabular}{|l|l|l|l|l|l|l|}
\hline Tamowicz $2007^{28}$ & RCT & 20 & 20 & ICU & 10 & N/A \\
\hline Maurya $2011^{29}$ & RCT & 20 & 20 & NICU & 1 & $30 \mathrm{kcal} / \mathrm{kg} /$ day \\
\hline Abdelsalam $2012^{30}$ & PO & 20 & 20 & ICU & 3 & $25 \mathrm{kcal} / \mathrm{kg} /$ day \\
\hline Kadamani $2014^{31}$ & RCT & 15 & 15 & ICU & 3 & N/A \\
\hline $\begin{array}{l}\text { Tavares De Araujo } \\
2013^{32}\end{array}$ & RCT & 23 & 18 & ICU & 5 & $25-30 \mathrm{kcal} / \mathrm{kg} /$ day \\
\hline Shahriari $2015^{33}$ & PO & 25 & 25 & ICU & 4 & Harris-Benedict equation \\
\hline Evans $2016^{34}$ & RCT & 24 & 26 & ICU & 17 & N/A \\
\hline Yagan $2017^{35}$ & RCT & 19 & 18 & ICU & 14 & Harris-Benedict equation \\
\hline McNelly $2020^{36}$ & RCT & 59 & 62 & ICU & 10 & $25 \mathrm{kcal} / \mathrm{kg} /$ day \\
\hline
\end{tabular}

Legend to Table 1.- * C-EN through nasogastric tube + C-EN through nasojejunal tube. $\mathrm{RCT}=$ randomized clinical trial; $\mathrm{PO}=$ prospective observational $\mathrm{RO}=$ retrospective observational. $\mathrm{ICU}=$ General Intensive Care Unit; NICU= Neurological/Neurosurgery Intensive Care Unit; CS-ICU= Cardiac Surgery Intensive Care Unit; TICU= Trauma Intensive Care Unit

Table 2: Summery of the effects of C-EN or I-EN on nutritional status

\begin{tabular}{|c|c|c|c|c|c|c|c|c|c|c|c|}
\hline Studies & $\begin{array}{l}\text { Days } \\
\text { in } \\
\text { targe } \\
\mathrm{t} \\
\text { nutriti } \\
\text { on/ } \\
\text { total } \\
\text { days } \\
\text { C-EN } \\
\text { vs I- } \\
\text { EN }\end{array}$ & $\begin{array}{l}\text { Total } \\
\text { amoun } \\
t \text { of } \\
\text { deliver } \\
\text { ed } \\
\text { feedin } \\
\text { g } \\
\text { volum } \\
\text { e } \\
\text { C-EN } \\
\text { vs } \\
\text { I-EN }\end{array}$ & $\begin{array}{l}\text { Time } \\
\text { neces } \\
\text { sary } \\
\text { to } \\
\text { achiev } \\
\text { e } \\
\text { prescri } \\
\text { bed } \\
\text { caloric } \\
\text { prescri } \\
\text { bed } \\
\text { goal } \\
\text { C-EN } \\
\text { vs } \\
\text { I- } \\
\text { EN }\end{array}$ &  & $\begin{array}{l}\text { Differe } \\
\text { nces in } \\
\text { BGC } \\
\text { betwee } \\
\text { n C-EN } \\
\text { and I- } \\
\text { EN }\end{array}$ & $\begin{array}{l}\text { Daily } \\
\text { mea } \\
n \\
\text { calori } \\
\mathrm{c} \\
\text { intak } \\
\text { e } \\
\text { betw } \\
\text { een } \\
\text { C- } \\
\text { EN, } \\
\text { I-EN } \\
\text { and } \\
\text { C-EN } \\
\text { jejun } \\
\text { al }\end{array}$ & $\begin{array}{l}\text { Mean } \\
\text { weight } \\
\text { loss } \\
\text { betwe } \\
\text { en C- } \\
\text { EN } \\
\text { and I- } \\
\text { EN }\end{array}$ & $\begin{array}{l}\text { Glucos } \\
\text { e } \\
\text { variabil } \\
\text { ity } \\
\text { and } \\
\text { insulin } \\
\text { utilizati } \\
\text { on } \\
\text { betwe } \\
\text { en C- } \\
\text { EN } \\
\text { and I- } \\
\text { EN }\end{array}$ & $\begin{array}{l}\text { Leptin } \\
\text { and } \\
\text { ghrelin } \\
\text { blood } \\
\text { levels } \\
\text { betwee } \\
\text { n C-EN } \\
\text { and I- } \\
\text { EN }\end{array}$ & $\begin{array}{l}\text { The } \\
\text { RQ } \\
\text { and } \\
\text { REE } \\
\text { betw } \\
\text { een } \\
\text { C-EN } \\
\text { and } \\
\text { I-EN }\end{array}$ & $\begin{array}{l}\text { Patie } \\
\text { nts } \\
\text { achie } \\
\text { ving } \\
\text { target } \\
\text { of } \\
\text { protei } \\
\text { n and } \\
\text { calori } \\
\text { c goal } \\
\text { C-EN } \\
\text { vs I- } \\
\text { EN }\end{array}$ \\
\hline $\begin{array}{l}\text { Kocan } \\
1986^{19}\end{array}$ & - & - & $\begin{array}{l}4.2 \text { vs } \\
5.2 \\
\text { days } \\
2^{\text {nd }}\end{array}$ & - & - & - & $\begin{array}{l}1.2 \mathrm{vs} \\
1.6 \mathrm{~kg} \\
2^{\text {nd }}\end{array}$ & - & - & - & - \\
\hline Steeve & $0 / 7$ & - & - & $12 \pm 5$ & - & - & - & - & - & - & - \\
\hline
\end{tabular}

This article is protected by copyright. All rights reserved. 


\begin{tabular}{|c|c|c|c|c|c|c|c|c|c|c|c|}
\hline $\begin{array}{l}\text { ns } 2002 \\
22\end{array}$ & \begin{tabular}{|l|} 
vs \\
$2 / 7$ \\
$1^{\text {st }}$ \\
\end{tabular} & & & $\begin{array}{l}\text { vs } \\
11 \pm 3 \\
1^{\text {st }} \\
14 \pm 10 \\
\text { vs } 16 \\
\pm 9\end{array}$ & & & & & & & \\
\hline $\begin{array}{l}\text { Rhoone } \\
\text { y } 2002 \\
23\end{array}$ & - & - & $\begin{array}{l}3.3 \mathrm{vs} \\
4.6 \\
\text { days }^{*} \\
1^{\mathrm{s}}\end{array}$ & - & - & - & - & - & - & - & - \\
\hline $\begin{array}{l}\text { Goward } \\
\text { man } \\
2003^{24}\end{array}$ & - & - & - & - & - & $\begin{array}{l}553 \\
\text { vs } \\
1173 \\
\text { vs } \\
1461 \\
* 1^{s}\end{array}$ & - & - & - & - & - \\
\hline $\begin{array}{l}\text { Serpa } \\
2003^{25}\end{array}$ & \begin{tabular}{|l|}
$0 / 3$ \\
vs \\
$1 / 3$ \\
$1^{s}$
\end{tabular} & $\begin{array}{l}\text { Day } 1 \\
614 \pm 1 \\
69 \\
\text { vs } \\
766 \pm 5 \\
5 * 1^{s}\end{array}$ & - & - & - & - & - & - & - & - & - \\
\hline $\begin{array}{l}\text { Chen } \\
2006^{26}\end{array}$ & - & $\begin{array}{l}58 \% \\
\text { vs } \\
92 \%^{\star *} \\
1^{s}\end{array}$ & - & - & - & - & - & - & - & - & - \\
\hline $\begin{array}{l}\text { Mac } \\
\text { Leod } \\
2007^{27}\end{array}$ & $\begin{array}{l}7 / 10 \\
\text { vs } \\
6 / 10 \\
1^{s}\end{array}$ & - & $\begin{array}{l}\text { No } \\
\text { differe } \\
\text { nce } \\
\text { betwe } \\
\text { en the } \\
2 \\
\text { groups } \\
1^{\text {s }}\end{array}$ & - & - & - & - & - & - & - & - \\
\hline $\begin{array}{l}\text { Maurya } \\
2011^{29}\end{array}$ & - & - & - & - & - & - & $\begin{array}{l}\text { No } \\
\text { differe } \\
\text { nces } \\
1^{\mathrm{s}}\end{array}$ & - & - & $\begin{array}{l}0.8 \\
\text { vs } \\
0.86 \\
/ \\
1527 \\
\text { vs. } \\
1599 \\
\text { kcal/ } \\
\text { day } \\
1^{\mathrm{s}}\end{array}$ & - \\
\hline
\end{tabular}

This article is protected by copyright. All rights reserved. 


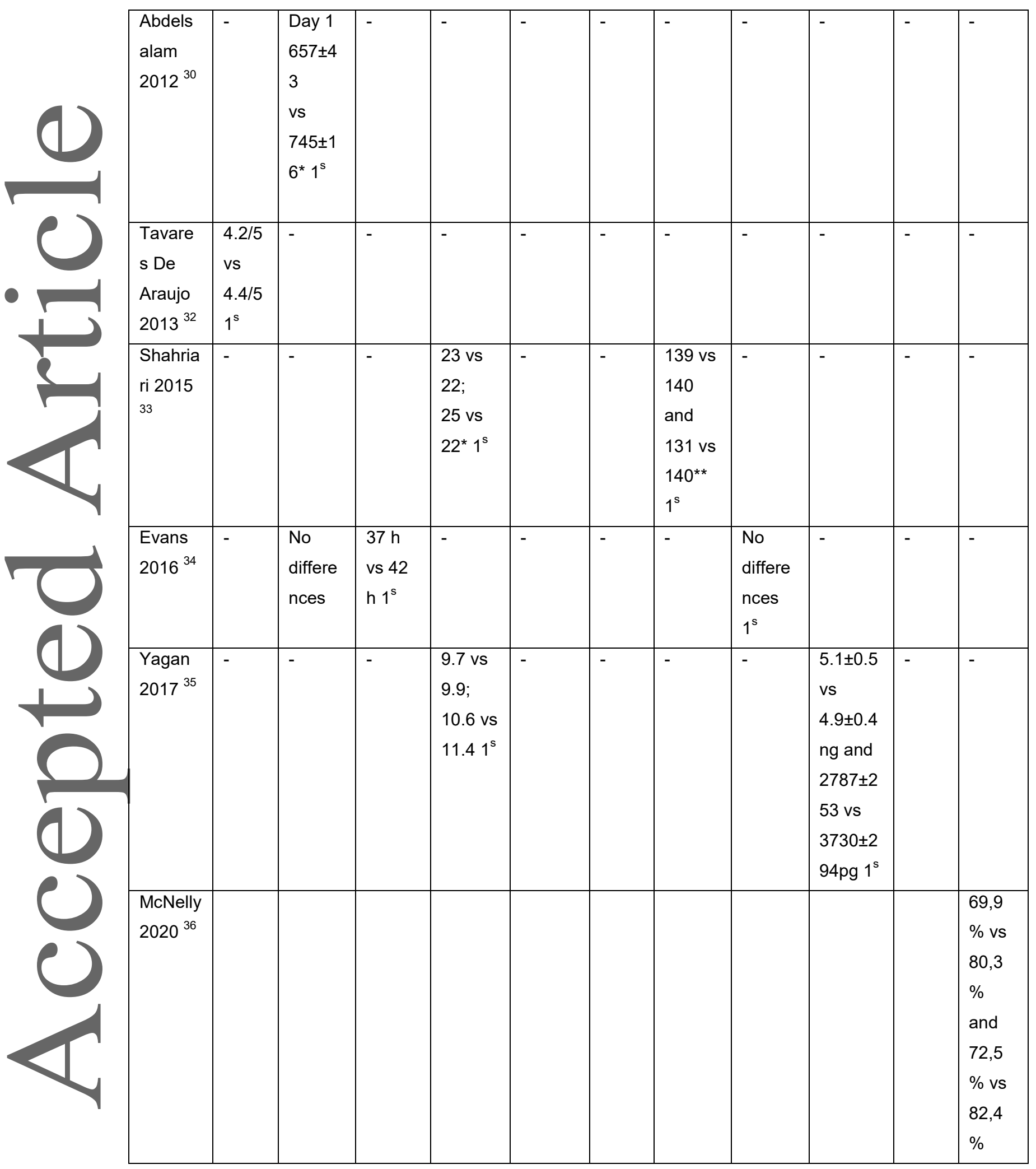

Legend to Table 2

BGC: Blood Glucose Concentrations; ${ }^{* *}$ number of patients with feeding volume administered >1000 ml/day; *** $100 \%(19), 80 \%(22,34)$ and $75 \%(23)$ of caloric prescribed.

This article is protected by copyright. All rights reserved. 
Differences in BGC between C-EN and I-EN: First day and last day values of study period were reported. $1^{\mathrm{s}} \mathrm{First}$ outcome; $2^{\text {nd }}$ Secondary recorded variable

${ }^{*} p<0.05$

Table 3 Summary of the effects of C-EN or I-EN on gastrointestinal symptoms or tolerance

\begin{tabular}{|c|c|c|c|c|c|c|c|c|c|c|c|}
\hline Studies & $\begin{array}{l}\text { Freque } \\
\text { ncy of } \\
\text { stool }\end{array}$ & $\begin{array}{l}\text { Consiste } \\
\text { nce of } \\
\text { stool }\end{array}$ & $\begin{array}{l}\text { Amo } \\
\text { unt } \\
\text { of } \\
\text { stool }\end{array}$ & $\begin{array}{l}\text { Differen } \\
\text { ces } \\
\text { betwee } \\
\mathrm{n} \\
\text { C-EN } \\
\text { and l- } \\
\text { EN }\end{array}$ & $\begin{array}{l}\text { Cut } \\
\text { off } \\
\text { of } \\
\text { GR } \\
V\end{array}$ & $\begin{array}{l}\text { Time } \\
\text { s } \\
\text { wich } \\
\text { GRV } \\
\text { was } \\
\text { check } \\
\text { ed }\end{array}$ & $\begin{array}{l}\text { Differe } \\
\text { nce of } \\
\text { GRV } \\
\text { betwee } \\
n \\
\text { C-EN } \\
\text { vs I- } \\
\text { EN }\end{array}$ & $\begin{array}{l}\text { Patie } \\
\text { nts } \\
\text { with } \\
\text { at } \\
\text { least } \\
1 \\
\text { episo } \\
\text { de of } \\
\text { vomiti } \\
\text { ng } \\
\text { (C- } \\
\text { EN } \\
\text { vs I- } \\
\text { EN) }\end{array}$ &  & $\begin{array}{l}\text { Patients } \\
\text { with } \\
\text { constipa } \\
\text { tion (C- } \\
\text { EN vs I- } \\
\text { EN) } \\
* * * * *\end{array}$ & $\begin{array}{l}\text { Gastri } \\
\text { c pH } \\
\text { betwe } \\
\text { en C- } \\
\text { EN vs } \\
\text { I-EN } \\
\text { patie } \\
\text { nts } \\
* * * * * \\
\text { * }\end{array}$ \\
\hline $\begin{array}{l}\text { Trudy } \\
1982^{18}\end{array}$ & $\begin{array}{l}2 \text { or } \\
\text { more/2 } \\
4 \mathrm{~h}\end{array}$ & $\begin{array}{l}\text { Liquid, } \\
\text { unforme } \\
\text { d }\end{array}$ & $\mathrm{N} / \mathrm{A}$ & $\begin{array}{l}6 / 8 \text { vs } \\
2 / 51^{s}\end{array}$ & - & - & - & - & - & - & - \\
\hline $\begin{array}{l}\text { Kocan } \\
1986^{19}\end{array}$ & $n / 24 h$ & $\begin{array}{l}\text { Walike } \\
\text { Scale } \\
\text { (W.S.) }\end{array}$ & $\mathrm{N} / \mathrm{A}$ & $\begin{array}{l}1.56 / d a \\
\text { y and } \\
3.69 \\
\text { W.S. vs } \\
1.48 / d a \\
\text { y and } \\
3.97 \\
\text { W.S. } 1^{\text {s }}\end{array}$ & $\begin{array}{l}>1 \\
00 \\
\mathrm{ml} \\
\star \star\end{array}$ & $\begin{array}{l}\text { Every } \\
4 \mathrm{~h}\end{array}$ & $\begin{array}{l}15.8 \\
\mathrm{ml} \mathrm{vs} \\
21.8 \\
\mathrm{ml}^{\star * *} \\
1^{\mathrm{s}}\end{array}$ & - & - & - & - \\
\hline $\begin{array}{l}\text { Bonten } \\
1996^{20}\end{array}$ & - & - & - & - & - & - & - & - & - & - & $\begin{array}{l}3.2 \text { vs } \\
2.5^{*} \\
(\mathrm{GM}) \\
1^{\mathrm{s}}\end{array}$ \\
\hline $\begin{array}{l}\text { Spilker } \\
1996^{21}\end{array}$ & - & - & - & - & - & - & - & - & - & - & $\begin{array}{l}\text { N/A } \\
(\mathrm{GM}) \\
1^{\mathrm{s}}\end{array}$ \\
\hline $\begin{array}{l}\text { Steeven } \\
\text { s } 2002^{22}\end{array}$ & $\begin{array}{l}3 \text { or } \\
\text { more/2 } \\
4 \mathrm{~h}\end{array}$ & Liquid & $\begin{array}{l}>250 \\
\mathrm{ml}\end{array}$ & $\begin{array}{l}2 / 9 \text { vs } \\
5 / 91^{s}\end{array}$ & $\begin{array}{l}>3 \\
00 \\
\mathrm{ml} \\
\star *\end{array}$ & $\begin{array}{l}\text { Every } \\
4 \text { h or } \\
\text { befor } \\
\text { e }\end{array}$ & $\begin{array}{l}33 \% \\
\text { vs } \\
55 \% \text { *** } \\
*\end{array}$ & - & - & - & - \\
\hline
\end{tabular}




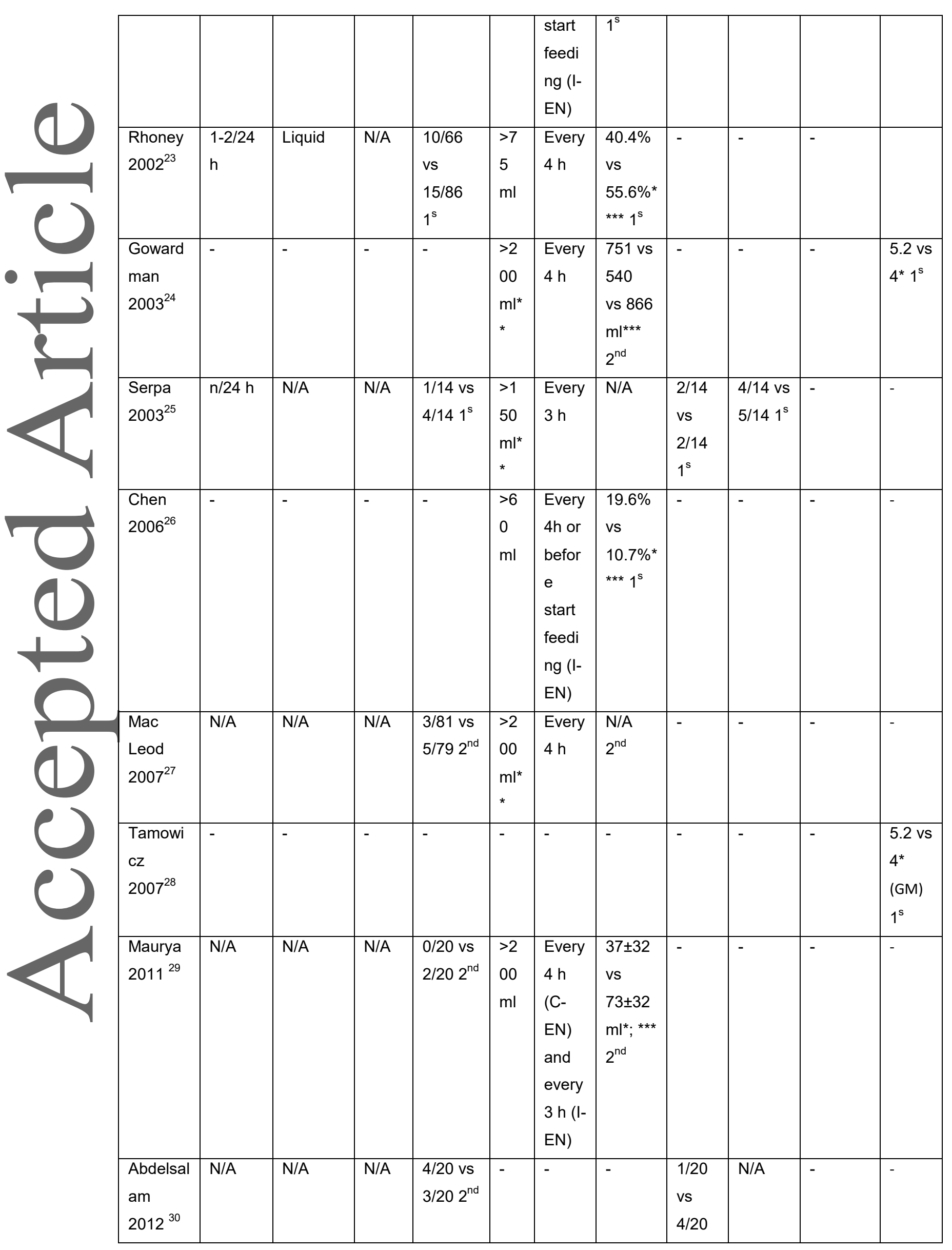

This article is protected by copyright. All rights reserved. 


\begin{tabular}{|c|c|c|c|c|c|c|c|c|c|c|c|}
\hline & & & & & & & & $2^{\text {nd }}$ & & & \\
\hline $\begin{array}{l}\text { Kadama } \\
\text { ni } \\
2014^{31}\end{array}$ & $\begin{array}{l}3 \text { or } \\
\text { more/2 } \\
4 \mathrm{~h}\end{array}$ & N/A & $\mathrm{N} / \mathrm{A}$ & $\begin{array}{l}6 / 23 \text { vs } \\
5 / 181^{s}\end{array}$ & $\begin{array}{l}>2 \\
00 \\
\mathrm{ml}\end{array}$ & $\begin{array}{l}\text { Every } \\
4 \mathrm{~h}\end{array}$ & $\begin{array}{l}13.3 \% \\
\text { vs } \\
20 \% 1^{s}\end{array}$ & - & - & $\begin{array}{l}10 / 15 \\
\text { vs } \\
3 / 15^{*} \\
1^{\mathrm{s}}\end{array}$ & - \\
\hline $\begin{array}{l}\text { Tavares } \\
\text { De } \\
\text { Araujo } \\
2013^{32}\end{array}$ & $\mathrm{~N} / \mathrm{A}$ & $\mathrm{N} / \mathrm{A}$ & \begin{tabular}{|l}
$\mathrm{N} / \mathrm{A}$ \\
\end{tabular} & $\begin{array}{l}6 / 23 \text { vs } \\
5 / 182^{\text {nd }}\end{array}$ & $\begin{array}{l}>2 \\
50 \\
\mathrm{ml}^{*} \\
*\end{array}$ & $\begin{array}{l}\text { Befor } \\
\text { e } \\
\text { start } \\
\text { feedi } \\
\mathrm{ng}\end{array}$ & $\begin{array}{l}\text { No } \\
\text { cases } \\
\text { of } \\
\text { GRV }\end{array}$ & $\begin{array}{l}7 / 23 \\
\text { vs } \\
4 / 18 \\
2^{\text {nd }}\end{array}$ & - & - & - \\
\hline $\begin{array}{l}\text { Yagan } \\
2017^{35}\end{array}$ & N/A & $\mathrm{N} / \mathrm{A}$ & \begin{tabular}{|l}
$\mathrm{N} / \mathrm{A}$ \\
\end{tabular} & $\begin{array}{l}2 / 19 \text { vs } \\
1 / 182^{\text {nd }}\end{array}$ & $\begin{array}{l}>2 \\
50 \\
\mathrm{ml}\end{array}$ & $\begin{array}{l}\text { Every } \\
4-6 \mathrm{~h}\end{array}$ & $\begin{array}{l}10 \% \\
\text { vs } \\
5 \% 2^{\text {nd }}\end{array}$ & $\begin{array}{l}0 / 19 \\
\text { vs } \\
2 / 18 \\
2^{\text {nd }}\end{array}$ & - & - & - \\
\hline $\begin{array}{l}\text { McNelly } \\
2020^{36}\end{array}$ & N/A & $\begin{array}{l}\text { Bristol } \\
\text { Stool } \\
\text { Chart } \\
\text { score }\end{array}$ & \begin{tabular}{|l|}
$N / A$ \\
\end{tabular} & $\begin{array}{l}4 / 59 \text { vs } \\
0 / 622^{\text {nd }}\end{array}$ & $\begin{array}{l}>3 \\
00 \\
\mathrm{ml}^{*} \\
*\end{array}$ & - & $\mathrm{N} / \mathrm{A}$ & - & $\begin{array}{l}16 / 59 \\
\text { vs } 5 / 62 \\
2^{\text {nd }}\end{array}$ & $\begin{array}{l}/ 59 \text { vs } \\
0 / 622^{\text {nd }}\end{array}$ & - \\
\hline
\end{tabular}

Legend to Table 3.- ${ }^{* *}$ Studies in those GRV was a reason to stop EN; ${ }^{* * *}$ Amount of volume over the cut-off of GRV; ${ }^{* * * *} \%$ of patients over the cut-off of GRV of C-EN vs I-EN group. ${ }^{* \star * * *}$ Defined as an abdominal circumference increased $3 \mathrm{~cm}$ or more; ${ }^{* * \star * * \star}$ Defined as absent bowel movement for three consecutive days or more; ${ }^{* \star \star * \star * \star}$ Administration of I-EN vs interruption; GM= Use of gastric medication (sucralfate, proton pomp inhibitor, ranitidine, etc..); $1^{\text {s }}$ First outcome; $2^{\text {nd }}$ Secondary recorded variable; * $p<0.05$

Table 4: Summary of the effects of C-EN or I-EN on respiratory tract

\begin{tabular}{|l|l|l|l|l|l|}
\hline Studies & $\begin{array}{l}\text { Diagnosis of presence } \\
\text { of EN in TBA secretion }\end{array}$ & $\begin{array}{l}\text { Patients with } \\
\text { presence of EN } \\
\text { in TBA } \\
\text { secretion C-EN } \\
\text { vs I-EN }\end{array}$ & $\begin{array}{l}\text { Diagnosis of } \\
\text { Pneumonia }\end{array}$ & $\begin{array}{l}\text { Patients } \\
\text { with } \\
\text { pneumonia } \\
\text { C-EN vs I- } \\
\text { EN }\end{array}$ & $\begin{array}{l}\text { Extubation } \\
\text { rate } \\
\text { patients C- } \\
\text { EN vs I-EN }\end{array}$ \\
\hline $\begin{array}{l}\text { Trudy } \\
1982^{18}\end{array}$ & $\begin{array}{l}\text { Blue aniline, breath sounds } \\
\text { reduction } \\
\text { Cyanosis, X-ray }\end{array}$ & $2 / 8$ vs $1 / 61^{\text {s }}$ & - & - & - \\
\hline $\begin{array}{l}\text { Kocan } \\
1986^{19}\end{array}$ & Blue aniline & $1 / 9$ vs $3 / 111^{\text {s }}$ & - & - & - \\
\hline $\begin{array}{l}\text { Bonten } \\
1996^{20}\end{array}$ & - & - & $\begin{array}{l}\text { X-ray, fever, } \\
\text { presence of } \\
\text { microorganism in } \\
\text { TBA secretions }\end{array}$ & $\begin{array}{l}3 / 30 \text { vs } \\
5 / 301^{\text {s }}\end{array}$ & - \\
& & & & \\
\hline
\end{tabular}

This article is protected by copyright. All rights reserved. 


\begin{tabular}{|c|c|c|c|c|c|}
\hline $\begin{array}{l}\text { Steevens } \\
2002^{22}\end{array}$ & Blue aniline & $0 / 9$ vs $1 / 91^{s}$ & - & - & - \\
\hline $\begin{array}{l}\text { Rhoney } \\
2002^{23}\end{array}$ & - & - & $\begin{array}{l}\text { X-ray, fever } \\
\text { leukocytosis } \\
\text { and dyspnea }\end{array}$ & $\mathrm{N} / \mathrm{A} 1^{\mathrm{s}}$ & - \\
\hline $\begin{array}{l}\text { Serpa } \\
2003^{25}\end{array}$ & $\begin{array}{l}\text { Blue aniline, symptoms, X- } \\
\text { ray }\end{array}$ & $1 / 14$ vs $1 / 141^{\mathrm{s}}$ & X-Ray, Symptoms & N/A & - \\
\hline $\begin{array}{l}\text { Chen } \\
2006^{26}\end{array}$ & $\begin{array}{l}\text { Blue aniline, } \\
\text { Pulmonary aspiration } \\
\text { index: glucose in sputum, } \\
\text { wheezing, fever, aspiration } \\
\text { pneumonia patchs in x-ray }\end{array}$ & $\begin{array}{l}25,18,18 \\
26 / 51 \text { vs } 13,8 \\
15,8 / 56 ;{ }^{*} 1^{s}\end{array}$ & - & - & $\begin{array}{l}16 / 51 \text { vs } \\
34 / 56^{*} 2^{\text {nd }}\end{array}$ \\
\hline $\begin{array}{l}\text { Mac Leod } \\
2007^{27}\end{array}$ & - & - & $\mathrm{N} / \mathrm{A}$ & $\begin{array}{l}33 / 81 \text { vs } \\
38 / 792^{\text {nd }}\end{array}$ & - \\
\hline $\begin{array}{l}\text { Tamowicz } \\
2007^{28}\end{array}$ & - & - & $\begin{array}{l}\text { X-ray, fever, } \\
\text { leukocytosis, pO2 } \\
\text { reduction }\end{array}$ & $\begin{array}{l}7 / 20 \text { vs } \\
4 / 201^{s}\end{array}$ & - \\
\hline $\begin{array}{l}\text { Maurya } \\
2011^{29}\end{array}$ & $\mathrm{~N} / \mathrm{A}$ & $\begin{array}{l}/ 20 \text { vs } \\
0 / 202^{\text {nd }}\end{array}$ & - & - & - \\
\hline $\begin{array}{l}\text { Abdelsalam } \\
2012^{30}\end{array}$ & Blue aniline, X-Ray & $\begin{array}{l}0 / 20 \text { vs } \\
0 / 20\end{array}$ & X-ray & $\begin{array}{l}0 / 20 \text { vs } \\
0 / 201^{s}\end{array}$ & - \\
\hline $\begin{array}{l}\text { Kadamani } \\
2014^{31}\end{array}$ & $\begin{array}{l}\text { Blue aniline, desaturation, } \\
\text { cyanosis }\end{array}$ & $\begin{array}{l}0 / 15 \text { vs } \\
0 / 151^{s}\end{array}$ & - & - & - \\
\hline
\end{tabular}

Legend to table $4 .-1^{\mathrm{s}}$ First outcome; $2^{\text {nd }}$ Secondary recorded variable; * $p<0.05$

Table 5.- Risk of Bias in RCT

\begin{tabular}{|c|c|c|c|c|c|c|}
\hline I.D & $\begin{array}{l}\text { Sequence } \\
\text { generation }\end{array}$ & $\begin{array}{l}\text { Allocation } \\
\text { Concealment }\end{array}$ & $\begin{array}{l}\text { Blinding of } \\
\text { participants, } \\
\text { personnel } \\
\text { and } \\
\text { outcome } \\
\text { assessor }\end{array}$ & $\begin{array}{l}\text { Incomplete } \\
\text { outcome } \\
\text { data }\end{array}$ & $\begin{array}{l}\text { Selective } \\
\text { outcome } \\
\text { reporting }\end{array}$ & $\begin{array}{l}\text { Others } \\
\text { criteria }\end{array}$ \\
\hline
\end{tabular}




\begin{tabular}{|c|c|c|c|c|c|c|}
\hline $\begin{array}{l}\text { Trudy } \\
1982^{18}\end{array}$ & $\mathrm{H}$ & U & $\mathrm{U}$ & $\mathrm{H}$ & L & U \\
\hline $\begin{array}{l}\text { Kocan } 1986 \\
19\end{array}$ & $\mathrm{H}$ & U & $\mathrm{U}$ & $\mathrm{L}$ & $\mathrm{L}$ & $\mathrm{H}$ \\
\hline $\begin{array}{l}\text { Bonten } \\
1996^{20}\end{array}$ & L & L & U & $\mathrm{L}$ & L & U \\
\hline $\begin{array}{l}\text { Steevens } \\
2002^{22}\end{array}$ & $\mathrm{~L}$ & U & U & $\mathrm{L}$ & $\mathrm{L}$ & $\mathrm{U}$ \\
\hline $\begin{array}{l}\text { Gowardman } \\
2003^{24}\end{array}$ & L & L & U & $\mathrm{L}$ & $\mathrm{L}$ & $\mathrm{U}$ \\
\hline $\begin{array}{l}\text { Serpa } \\
2003^{25}\end{array}$ & $\mathrm{U}$ & $\mathrm{L}$ & $\mathrm{U}$ & $\mathrm{U}$ & $\mathrm{L}$ & $\mathrm{H}$ \\
\hline $\begin{array}{l}\text { Chen } \\
2006^{26}\end{array}$ & $\mathrm{U}$ & $\mathrm{L}$ & $\mathrm{U}$ & $\mathrm{L}$ & $\mathrm{L}$ & $\mathrm{U}$ \\
\hline $\begin{array}{l}\text { Mac Leod } \\
2007^{27}\end{array}$ & L & L & U & L & L & $\mathrm{L}$ \\
\hline $\begin{array}{l}\text { Tamowicz } \\
2007^{28}\end{array}$ & $\mathrm{U}$ & L & $\mathrm{U}$ & $\mathrm{L}$ & $\mathrm{L}$ & $U$ \\
\hline $\begin{array}{l}\text { Maurya } \\
2011^{29}\end{array}$ & $\mathrm{~L}$ & $\mathrm{~L}$ & $\mathrm{U}$ & $\mathrm{L}$ & $U$ & $\mathrm{~L}$ \\
\hline
\end{tabular}

This article is protected by copyright. All rights reserved. 


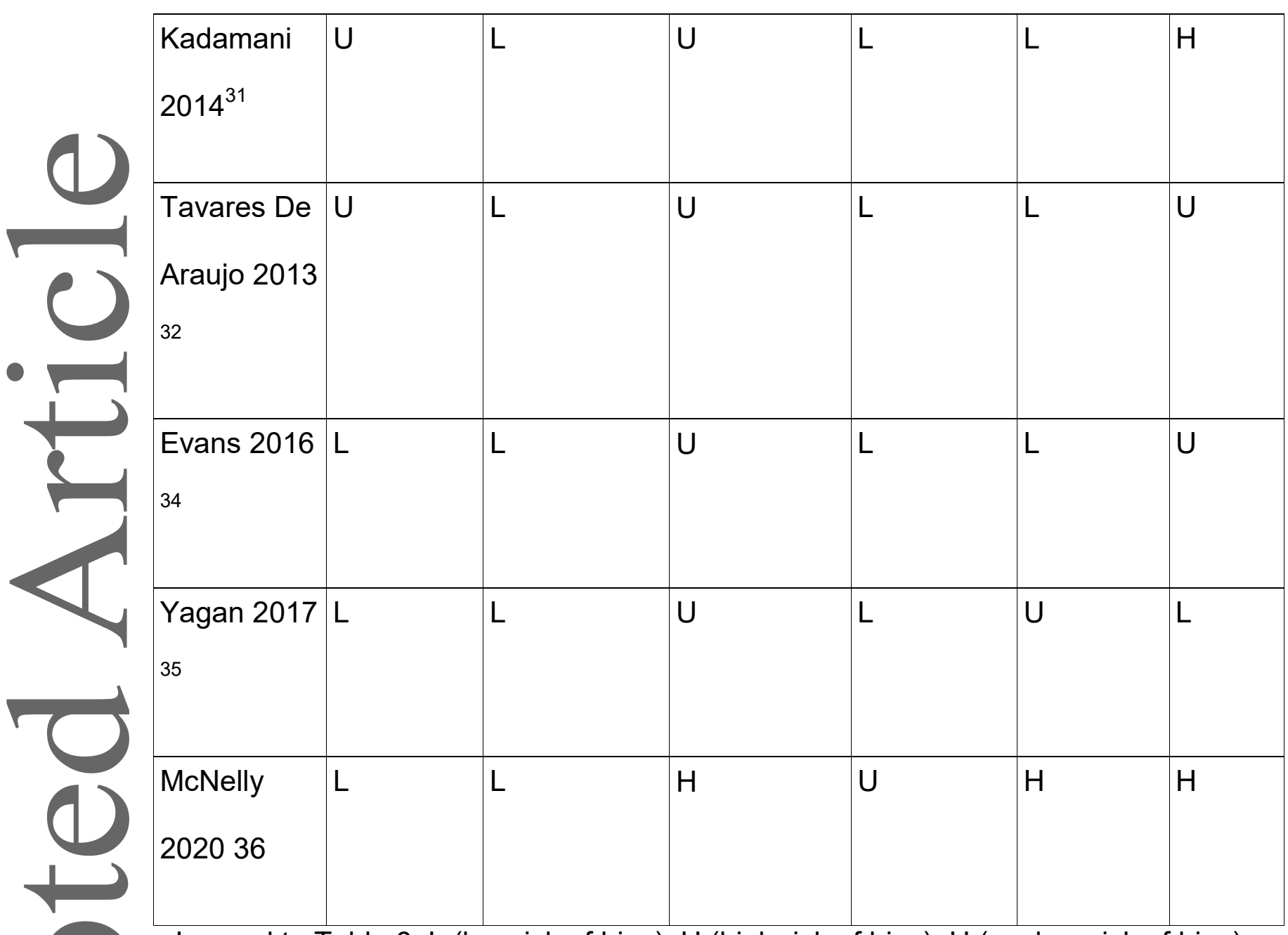

Legend to Table 6: $\mathrm{L}$ (low risk of bias); $\mathrm{H}$ (high risk of bias); $\mathrm{U}$ (unclear risk of bias). 
Table 6.- Risk of Bias of non RCT



Legend to Table 7. L (low risk of bias); M (moderate risk of bias); S (serious risk of bias); C (critical risk of bias); U (unclear risk of bias) 
Figure 1 PRISMA summary literature search

Fig.1.- PRISMA summary literature search
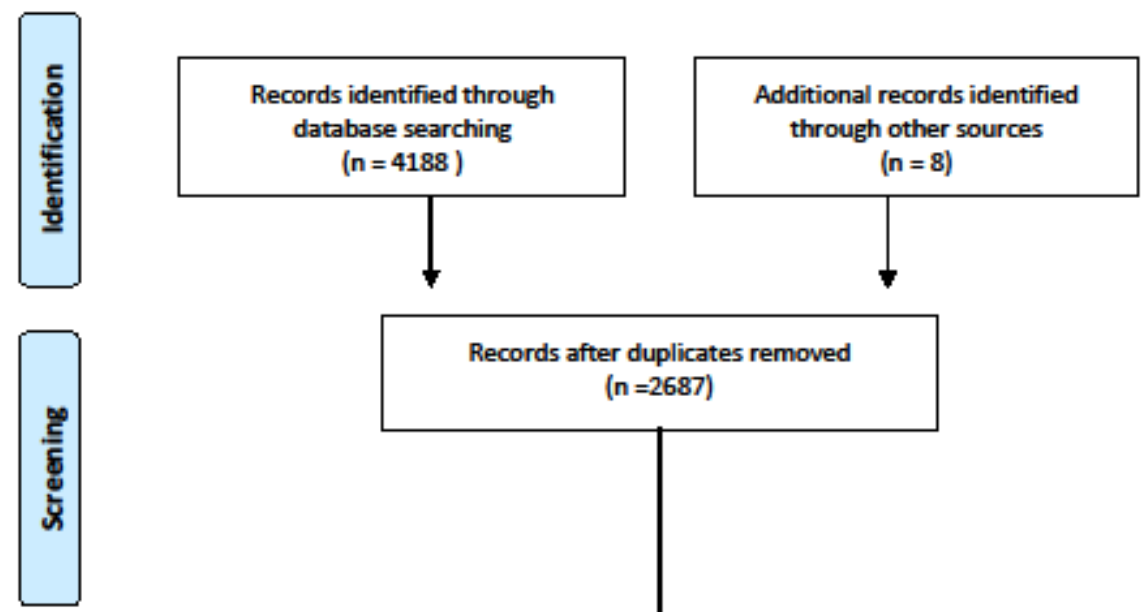

Records after duplicates removed ( $n=2687$ )


Studies included in qualitative synthesis

Records excluded $(n=1491$ )

- Irrelevant publication type (936)

- Not full text (357)

Animals (56)

- No English (15)

- Not in ICU (55)

Pediatric patients (59)

- Combined with PN (13)

From: Moher D, Lberatl A, Tetziat J, Attman DG, The PRISMA Group (2009). Preferred Reporting Hems for Systematic Revlews and Meta Analyses: The PRISMA Statement. PLOS Med 6(6): e1000097. do: 10.1371/journal.pmedic00097

For more information, visit www.prisma-tratement.orf

This article is protected by copyright. All rights reserved. 